\title{
Introduction
}

\section{Beyond the BRICs: Alternative Strategies of Influence in the Global Politics of Development}

\author{
Matthias vom $\mathrm{Hau}^{\mathrm{a}, *}$, James Scott ${ }^{\mathrm{b}}$ and David Hulme ${ }^{\mathrm{b}}$

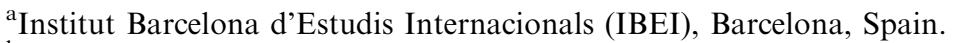 \\ ${ }^{\mathrm{b}}$ Brooks World Poverty Institute, Humanities Bridgeford Street Building, University of Manchester, \\ Manchester, UK. \\ *E-mail: mvomhau@ibei.org
}

\begin{abstract}
This introductory essay situates the subsequent special issue within a comparative framework that helps to unpack the new global politics of development. It argues that there is a set of countries beyond Brazil, Russia, India and China - often described as 'the BRICs' - that are emerging to a position of increased international prominence and which merit greater attention than they have hitherto received. Recent economic risers such as South Africa, South Korea, Turkey and Mexico are responding to their economic growth and seeking to secure greater influence within regional and global affairs. The analytical framework developed here distinguishes between four distinct strategies of international engagement: issue leading, opportunity seeking, region organising and region mobilising. The framework further suggests the need to focus on new global opportunities and pressures, as well as the specific interests and capacities of states when accounting for the adoption of a particular strategy of engagement.

Cet essai d'introduction inscrit ce numéro spécial dans un cadre comparatif nous permettant d'analyser la nouvelle politique globale de développement. Il soutient qu'il existe un ensemble de pays au delà du Brésil, de la Russie, de l'Inde et de la Chine - souvent dénommé les pays 'BRICs'- qui sont en train de gagner en importance sur la scène internationale et qui méritent plus d'attention qu'ils $n$ 'ont reçu jusqu'à présent. Les pays en ascension économique récente tels que l'Afrique du Sud, la Corée du Sud, la Turquie, et le Mexique réagissent à leur croissance économique en s'efforçant d'accroître leur influence tant au niveau régional qu'international. Le cadre analytique développé dans cet essai distingue quatre stratégies d'engagement: Le leadership thématique, la recherche d'opportunités, l'organisation régionale et la mobilisation régionale. Ce cadre met également en avant le besoin de se pencher sur les nouvelles opportunités et contraintes se présentant au niveau mondial, ainsi que sur les intérêts et capacités spécifiques des États, pour comprendre et expliquer l'adoption de telle ou telle stratégie d'engagement.
\end{abstract}

European Journal of Development Research (2012) 24, 187-204. doi:10.1057/ejdr.2012.6

Keywords: International development; global governance; foreign policy; economic growth; rising powers; regional powers

\section{Introduction}

Over recent decades, the growing economic and political power of Brazil, Russia, India and China, the so-called BRICs, has obtained widespread attention. ${ }^{1}$ Scholars investigate the reasons behind the spectacular economic growth of those countries and the political implications of their recent rise for areas as diverse as global governance, democratisation, 
trade policy and social provision (for example, Segal, 1999; Ramo, 2004; Friedberg, 2005; Macfarlane, 2006; Soares de Lima and Hirst, 2006; Narlikar, 2010). Indeed, 20 years ago, it would have been difficult to imagine Brazil as the main regional leader in Latin America, India as a major player in the World Trade Organization (WTO), or China as the second largest economy in the world, having overtaken Japan in 2010. The growth achieved by China is historically unprecedented, outpacing that of any country in history, and the economic 'jump' of India and China is responsible for reversing the century-long trend towards rising world income inequality between nations (Korzeniewicz, 2012; Milanovic, 2010).

Yet, the rise of the BRICs is not the whole story. An exclusive focus on Brazil, India and China overlooks other important changes that are taking place in the international arena. It is true - most countries have been characterised by substantial stability of their relative levels of development. Low-income and middle-income countries during the 1980s largely continue to be low-income and middle-income countries today (Wade, 2010). However, the BRICs are not the only exceptions to this overall trend. Countries as diverse as Mexico, South Korea and Turkey have significantly improved their relative standings within the global income hierarchy. Similarly, an exclusive focus on the BRICs ignores the new South-South dynamics that are altering global politics. These include, to name just a few prominent examples, South Africa becoming a regional powerhouse in sub-Saharan Africa, South Korea becoming a significant new source of Foreign Direct Investment (FDI) and Overseas Development Assistance (ODA), and Turkey becoming a champion of Millennium Development Goals (MDG) implementation in neighbouring countries. We thus need more systematic knowledge about what goes on 'beyond the BRICs'.

This article, and the collection of comparative case studies it introduces, is a first step towards looking beyond Brazil, India and China towards other countries that have become increasingly influential in the field of global development. We combine insights from international relations and development studies into the role played by economic risers such as South Africa, South Korea, Turkey and $\mathrm{Mexico}^{2}$ in global governance institutions and their engagement with developing countries. We also seek to explore the reasons for particular political responses to the economic growth experienced by those states, and unpack possible implications of their international engagement for the global politics of development.

Similar to the BRICs, South Korea, South Africa, Turkey and Mexico are among the upward movers in the global economic order. As a matter of fact, these four states are at the forefront of this special issue because all of them have improved their relative standing within the global income hierarchy (Korzeniewicz, 2012). ${ }^{3}$ Yet, these states must be analysed in a separate category to the BRICs. Brazil, India and China are important already, simply because of their size and high economic growth. These factors indicate that the BRICs are likely to become great powers - not hegemonic, nor in the foreseeable future challenging US hegemony, but highly influential within the international sphere. South Korea, South Africa, Turkey and Mexico do not command what Barnett and Duvall (2004, p. 13) term 'compulsory power' - the capacity of one actor to 'shape directly the circumstances and/or actions of another'. They lack the military resources to dominate other countries and lack the economic resources to bribe countries into adopting policies that they would not otherwise pursue. Simultaneously, these states also differ from the small or 'system ineffectual' states (in Robert Keohane's [1969] terminology), having a greater degree of influence than those falling into this 
category. This international influence tends to be built around the exercise of soft power (Nye, 1990).

This article therefore has three major aims.

- The first goal is to identify how recent economic risers beyond the BRICs project political influence in the global politics of development. On the basis of the comparative case studies assembled in this special issue, we suggest that it is useful to distinguish between at least four analytically distinct strategies of exercising international influence, differentiated by their target and geographical scope. Issue leading is centred on policymaking in global governance institutions such as the WTO or the United Nations (UN) and involves coalition building and group formation. Opportunity seeking is also a global strategy of international engagement, but focuses on establishing close bilateral relations in the form of trade agreements with and/or strategic investments in particular countries. Region organising is concerned with leadership in organisations that represent a geographically and/or culturally defined area, whereas region mobilising focuses on economic integration within a particular region and often involves a 'bridging' role as a regional hub. The analytical focus on distinct strategies establishes a flexible tool for tracing forms of international engagement across different cases and time periods. It also provides a distinct advantage over identifying particular countries with a circumscribed role - as suggested by classifications such as 'middle powers', 'regional powers', 'semi-peripheral countries' or 'anchor countries'.

- The second goal is to examine why South Africa, South Korea, Turkey and Mexico have adopted a particular strategy (or combination thereof), and how these modes of international engagement are connected to domestic and global dynamics. The framework that informs this special issue suggests the need to focus on new global opportunities and pressures, as well as the interests and capacities of recent economic risers to engage internationally. Three specific factors are identified: (i) Economic globalisation and the rise of the BRICs have set the stage for new forms of international engagement; (ii) Domestic politics and political economy dynamics, in particular access to natural resources, state-business relations, civil society networks and economic inequalities motivate state authorities to adopt a particular mode of international engagement; (iii) Symbolic resources, institutional resources, and the position vis-à-vis great powers and 'recipient states' shape the capacity of economic risers to engage in issue leadership, global opportunity seeking, regional organising and/or regional mobilising.

- The third goal is to explore how these distinct strategies of international projection impact on the global politics of development. Here we emphasise that Mexico, South Africa, South Korea and Turkey are unlikely to become as influential as the BRICs, which are endowed with the capacity to act as system changers in the global development regime. However, countries such as those examined in this special issue frequently adapt to new international opportunities and pressures and, under certain conditions, these countries amend the global politics of development by becoming policy leaders in global governance institutions and/or carving out an (often regionally and culturally bounded) niche of international influence. In other words, the case studies assembled in this special issue show that there is space for incremental change within the global order, and that this change is propelled by countries emerging in the shadow of the BRICs. 
The subsequent sections will follow the structure of this argument. The conclusion will also lay out a methodological and conceptual roadmap for the comparative case studies to come and provide an overview of the individual papers.

\section{Strategies of International Engagement}

The countries dealt with in this special issue, and their methods of power projection, are diverse. South Africa, South Korea, Turkey and Mexico experienced distinct trajectories of development. Their incorporation into the global capitalist economy and the international state system followed radically different paths - just compare the contrasting colonial legacies left behind in Mexico and South Korea (see Lange et al, 2006; Kohli, 2009), or the distinct strategic roles played by Turkey and South Africa during the Cold War era (see Barber and Barratt, 1990; Aydin, 2000). Or contrast, the recent democratic transitions in those countries, or the levels of economic development they exhibit in relation to each other.

At the same time, these four countries share important features when analysed with respect to their position within the global economic order. As Patricio Korseniewicz shows in this special issue, Mexico, South Korea, Turkey and, to a lesser extent, South Africa are all economic risers; for at least the last 15 years they have been characterised by significant economic growth. Moreover, these four countries are all late developers with sizeable landmass and populations, in which the state has been crucial in imposing macroeconomic development policies (Waldner, 1999; Amsden, 2001).

The question that follows is: How do South Africa, South Korea, Turkey and Mexico project international power? Drawing on Robert Keohane's work (1969, p. 295), these four countries may be classified as 'system affecting states', which 'cannot hope to affect the system acting alone [but] can nevertheless exert significant impact on the system by working through small groups or alliances or through universal or regional international organisations'. On the basis of Keohane's distinction between organisations and countries, we distinguish between two basic dimensions when identifying modes of international engagement found among these countries. As shown in Table 1, the first dimension concerns the venue of influence and contrasts a strategy that seeks to exercise influence through coalition-building and agenda-setting within international organisations, with a strategy that focuses on individual or small groups of countries and works primarily through agreements, treaties or mediation. The second dimension traces the geographical scope of international policymaking by pinpointing whether the engagement is regionally bounded or global in scope and ambition.

On the basis of this distinction, it is possible to identify at least four major modes of international engagement. As Table 2 illustrates, issue leaders operate at a global level and

Table 1: Modes of international engagement

\begin{tabular}{lll}
\hline Venue of influence & Geographical scope & \\
\cline { 2 - 3 } & Global & Regional \\
\hline International organisations & Issue leadership & Region organising \\
Countries & Opportunity seeking & Region mobilising \\
\hline
\end{tabular}


engage in policymaking in international organisations such as the WTO or the UN. Within such contexts, issue leadership often entails a multilateralist approach and the provision of intellectual leadership, technical support and political convening facilities. Influence is thus derived from the use of coalitions and consensus building. Among the four countries included in this special issue, South Korea constitutes an example of this mode of engagement. At the G20 Seoul summit in 2010, the Korean government managed to obtain G20 support for a 'Seoul Development Consensus' on how to tackle global poverty and volatile markets through the establishment of financial stability nets (Kalinowski and Cho, 2012). Another example is South Africa's role as an intermediary between developing and developed nations within the WTO. The country played a crucial role in forging consensus around the 2003 Decision on Trade Related Intellectual Property Rights (TRIPS) and Public Health, both in coordinating a common position among developing countries and then creating consensus around this position with the developed countries (Ismail, 2012; Jordaan, 2012).

Similar to issue leadership, opportunity seeking also unfolds on a global scale. Yet the main focus of engagement is countries, not organisations. Opportunity seeking involves the establishment of close bilateral relations with developing countries perceived as being of economic or strategic importance. These relations may take the form of free trade agreements, bilateral treaties or development partnerships, and are often coupled with strategic investments. South Korea again exemplifies this mode of engagement. During the last decade, the Korean government has pursued an aggressive bilateral free trade agreement strategy that reflects its export-oriented development model. This has been accompanied by a dramatic increase of ODA to developing countries around the world, especially in the form of loans that are linked to promoting exports and securing access to natural resources (Kalinowski and Cho, 2012). A similar strategy of international engagement has been pursued by Turkey. Over the recent decade, the Turkish government launched a new initiative to develop closer relations with selected countries in sub-Saharan Africa and Central Asia. This included the installation of new consulates across formerly neglected zones, the signing of trade protocols, the implementation of cultural exchange programmes and the expansion of ODA to these countries. In Africa, Turkey even acquired an observer status in the African Union in 2005, and was accepted as a non-regional member of the African Development Bank in 2008 (Apaydin, 2012).

Table 2: Mapping modes of international engagement

\begin{tabular}{|c|c|c|c|c|}
\hline & Issue leadership & $\begin{array}{l}\text { Opportunity } \\
\text { seeking }\end{array}$ & $\begin{array}{l}\text { Region } \\
\quad \text { organising }\end{array}$ & $\begin{array}{l}\text { Region } \\
\quad \text { mobilising }\end{array}$ \\
\hline $\begin{array}{l}\text { Venues of } \\
\text { influence }\end{array}$ & $\begin{array}{l}\text { International } \\
\text { institutions (for } \\
\text { example, WTO, } \\
\text { UN, G20) }\end{array}$ & $\begin{array}{l}\text { Bilateral } \\
\text { agreements; } \\
\text { FDI; ODA }\end{array}$ & $\begin{array}{l}\text { Regional } \\
\text { organisations } \\
\text { (for example, } \\
\text { NEPAD, } \\
\text { BSEC) }\end{array}$ & $\begin{array}{l}\text { Multilateral } \\
\text { agreements; } \\
\text { FDI; ODA }\end{array}$ \\
\hline $\begin{array}{l}\text { Main strategies } \\
\text { of influence }\end{array}$ & $\begin{array}{l}\text { Group formation; } \\
\text { coalition } \\
\text { building }\end{array}$ & $\begin{array}{l}\text { Export } \\
\text { facilitation; } \\
\text { market } \\
\text { governance }\end{array}$ & $\begin{array}{l}\text { Mediation among } \\
\text { great powers; } \\
\text { regional } \\
\text { identity }\end{array}$ & $\begin{array}{l}\text { Regional } \\
\text { economic hub; } \\
\text { market } \\
\text { governance }\end{array}$ \\
\hline Examples & $\begin{array}{l}\text { South Korea; } \\
\text { South Africa }\end{array}$ & $\begin{array}{l}\text { South Korea; } \\
\text { Turkey }\end{array}$ & $\begin{array}{l}\text { Turkey; South } \\
\text { Africa }\end{array}$ & South Africa \\
\hline
\end{tabular}


These global modes of international policymaking contrast with more regionally focused strategies of engagement. Region organising involves leadership in organisations that represent a geographically defined area. This kind of organisation provides a forum for the multilateral negotiation of security and economic concerns, and it also constitutes a venue for the ideological construction of a distinct regional identity. Within these organisational contexts, regional organisers often act as agenda-setters and mediators. South Africa is a case in point. The creation of the New Partnership for Africa's Development (NEPAD) has given the country a vehicle for extending its influence within sub-Saharan Africa. South Africa is recognised by member states as a leader on security and development goals, in exchange for maintaining a 'soft-soft' diplomacy towards authoritarian African leaders, such as Robert Mugabe's regime in Zimbabwe. In addition, Turkey works through regional organisations to project international power, as illustrated by the country's influence in the Black Sea Economic Cooperation (BSEC) forum and its role as a convener for the United Nations Economic Commission for Europe MDGs +10 deliberations (Baran, 2008).

The fourth mode of international engagement is also regional in orientation. Region mobilising focuses on the cultivation of strategic and economic ties with neighbouring countries, whether through multilateral or bilateral trade agreements, infrastructural investments or migration policy. Region mobilisers are usually economically, politically and ideologically well-integrated within a particular region, and often act as mediators for great powers and/or regional entry points for capital and trade. Among the case studies covered in this special issue, South Africa exemplifies this mode of international policymaking. Since 1994, the country has fostered bilateral relations to shape development within sub-Saharan Africa. Channels of influence include the systematic increase of FDI, government support for the expansion of South African companies into neighbouring markets, and the construction of port and road facilities to establish the country as a major regional economic hub (Carmody, 2012).

Even though South Africa illustrates that the distinction between region organising and region mobilising is a fluid one, the distinction remains analytically important. Countries may influence regional development primarily through organisational leadership, while not exhibiting the intention and/or capacities to engage through less formal bilateral relations, and vice versa. An example here is Indonesia. Through its regional leadership in the Association of Southeast Asian Nations, the country plays a dominant role in defining regional foreign policy goals that accommodate its own 'independent and active' agenda (Acharya, 2009), yet this organisational role has not entailed an encompassing strategy of regional involvement that is comparable with the influence projected by South Africa.

The preceding discussion also indicates that Mexico differs markedly from the other three countries included in this special issue. Whereas South Africa, South Korea and Turkey pursue regional leadership, establish South-South partnerships and/or broker deals within global institutions, Mexico does not follow any of these modes of international engagement. The country has ceased to be a regional organiser in Latin American foreign relations. Similarly, the country is not a global or even regional issue leader, as shown by Mexico's behaviour with respect to international property rights (Shadlen, 2012). Seen from this perspective, then, the country provides a cautionary tale about the 'rise and stall' of countries in the shadow of the BRICs. As a matter of fact, Mexico is included in the special issue as a 'negative case' - a country for which the projection of international influence is severely limited. 
In sum, the distinct modes of power projection presented in this section are thought of primarily as a heuristic device to identify the distinct strategies of international engagement displayed by three cases included in this special issue - South Africa, South Korea and Turkey. As such, the distinction between issue leadership, opportunity seeking, region organising and region mobilising attempts to move beyond the idiosyncrasies of each country, although it remains up to future research to explore whether this analytical grid might also provide insights beyond these cases. Moreover, the different modes of international engagement are not mutually exclusive. As the previous discussion has illustrated, individual countries might pursue several strategies at the same time. Our focus on distinct modes establishes a flexible tool for tracing forms of international power projection across different cases and time. This inbuilt flexibility provides a distinct advantage over identifying particular countries with a fixed role within the global order such as middle powers or regional powers. The four modes presented here are able to capture how recent economic risers such as South Africa, South Korea and Turkey adopt, combine and drop particular forms of international engagement. They also allow us to explore why other countries, such as Mexico, largely abstain from global or regional power projection.

\section{Domestic Dynamics, International Standing and Strategies of Engagement}

The question that follows is: Why did countries such as South Korea, South Africa and Turkey become more centrally involved in the global politics of development? Why did Mexico not follow a similar path? And how to explain variations in the particular route of international engagement (or combination thereof) taken by each of those countries? This section presents an analytical framework that identifies major determinants of international power projection. The framework combines insights from development studies and international relations in an eclectic manner while synthesising insights from the articles assembled in this special issue into a comparative perspective. As such, the framework does not pretend to be a parsimonious theory that can be applied seamlessly to a wide variety of cases. It also does not pretend to provide exhaustive historical explanations of the cases presented here. Rather, our goal is decidedly more modest: we wish to develop a theory frame that both draws on and steers the empirical case studies to come. ${ }^{4}$

\section{New Opportunities and Pressures}

Substantial changes in the world economic order and the international state system over the last 20 years have created new opportunities and pressures for South Korea, South Africa, Turkey and Mexico to become involved in the global politics of development. As a matter of fact, their economic rise is at least to some extent a result of those transformed economic and political relations. We suggest that the emergence of the BRICs, together with the push towards trade openness, financial liberalisation and the resulting intensification of global economic competitiveness constitute the backdrop against which these states have developed new forms of international political engagement.

The rise of the BRICs has opened up opportunities for other developing countries to increase their influence in the world. High and sustained growth rates among the BRICs and beyond have led to a partial decoupling of the global South from the OECD 
economies. Although the markets of the United States and the EU continue to be of immense importance, the emerging markets in the BRICs are the sites of significant new demand. Indeed, China has become the biggest trading partner for many developing countries, from South Africa and Brazil to Mali and the Democratic Republic of Congo. These shifting power relations have opened up new spaces for international political engagement. For example, there is the opportunity to act as intermediaries between the West and the BRICs, or between the BRICs and other developing countries. South Africa has managed to find a role for itself within the WTO doing precisely this, as it is trusted as a representative of other developing countries in a way in which the new powers of India and Brazil could never be (Jordaan, 2012). South Africa has also played a role in attempting to find compromises between the dominant players (the United States, the EU, India, China and Brazil). Leadership roles for countries such as South Africa have opened up precisely by the fact that they are not emerging great powers, such as the BRICs.

At the same time, the rise of the BRICs also poses new challenges for the developing world. The economic clout of Brazil, India and China has turned these countries into major players in the global scramble for natural resources, market access and investment opportunities. The sheer size of their economies and the increasing influence of their multinational companies enables the BRICs to advance their economic interests at a global scale, often with constraining effects on the economic and political activities of other emerging economies. South Africa is again a point in case. In sub-Saharan Africa, the country faces increasing competitive pressures from China. South African capital benefits from its role as an infrastructure and service provider for Chinese multinational companies, yet this regional division of labour also limits the ability of the South African state to act independently of Chinese interests in the context of global and regional governance institutions (Carmody, 2012). Similarly, Brazil's growing economic influence in Latin America and its emphasis on MERCOSUR (Mercado Común del Sur or Common Southern Market) as the main mechanism of regional integration has contributed to Mexico's marginalisation in the region (Phillips, 2003; Dosman, 2008).

Furthermore, globalisation has put new pressures on states, especially among those located in the semi-periphery of the global capitalist system. During the last three decades, most states around the world adopted a liberal economic model and opened up their national economies to global market forces. Trade barriers have been reduced, markets have been liberalised, with the result that goods and capital move around the globe in unprecedented volumes with unprecedented speed (Castells, 1997; Held et al, 1999). Many states in recently industrialising countries implemented an export-oriented development model, which entailed the searching for and promotion of new markets. The countries included in this special issue powerfully illustrate this new economic strategy. Their dependence on international trade and investment made it imperative for South Africa, South Korea, Turkey and Mexico to take on a more active role within the global governance of markets to facilitate trade, investment and capital flows abroad.

Yet the four countries have taken very different routes of international engagement to deal with the new multipolar world order and economic globalisation. The new opportunities and pressures confronted by these countries alone cannot account for the distinct modes of international policymaking found among these countries. It is therefore crucial to unpack how these global changes interacted with specific economic and political contexts at the national level. It is the interests and capacities of these four states to which we now turn. 


\section{Interests}

What factors motivate economic risers beyond the BRICS to engage in the global politics of development? The intent to build a new regional power base, take on an intermediary role in international organisations, provide ODA, or systematically invest in the infrastructure of other developing countries needs to be understood within the context of domestic politics and the political economy of a particular country. The internal distribution of political economic and ideological power, as well as the position relative to all other countries shapes the ways in which a country exercises international influence (Mann, 1993). Of particular importance in prompting particular modes of engagement are therefore natural resource access, state-business elite relations, the nature of civil society networks and within-nation inequalities.

The need to have available natural resources for sustaining economic growth greatly affects the international political projects of states (see for example Zweig and Jianhai, 2005; Cotula et al, 2009). Economic risers concerned about their access to oil, gas and other critical commodities often seek to expand their influence in potential supplier countries, whether those countries are located in their direct geographical neighbourhood or not. This strategy might include the signing of trade and investment agreements, as illustrated by Turkey's protocols of economic and political cooperation with Sudan (Apaydin, 2012), or South Korea's free trade agreement with Peru. ${ }^{5}$ Both Turkey and South Korea lack a domestic supply of oil and gas and therefore attempt to expand and diversify their access to natural resources around the world. Natural resource access thus appears to be a particularly forceful incentive for engaging in global opportunity seeking and regional mobilising.

Access to natural resources, however, plays little role in motivating issue leadership in global institutions such as the UN, the World Bank or the WTO. Power projection in the context of international organisations requires attention to domestic politics more broadly. Institutionalist analyses have long argued that sectorally determined business interests (Shafer, 1994) and the relative power of different and often contending business groups (Schneider, 2004) crucially shape the development policies chosen by a particular country. As some of the case studies assembled in this special issue illustrate, this perspective can be fruitfully extended to international policymaking. In South Korea, highly diversified chaebol that dominate the national private sector tend to have extensive foreign operations, including commodity chains in Southeast Asia. Accordingly, these conglomerates are very supportive of an ODA policy that systematically promotes Korean exports, for instance, through tied loans or infrastructural investments in selected countries (Kalinowski and Cho, 2012). In Mexico, by contrast, the relative weakness of the national pharmaceutical sector vis-à-vis international pharmaceutical companies led to the revision in the early 2000 s of the intellectual property rights regime around drugs that further exceeded the country's TRIPS and NAFTA requirements (Shadlen, 2012). Thus, in both of these distinct policy arenas, international aid and international property rights, business preferences and state-business coalitions gave rise to particular international projects.

It is important to note, however, that business-state relations is not the only vector in domestic politics that shapes engagement within the global politics of development. The case studies assembled in this special issue also reveal another critical force: the relative power and nature of civil society networks - and how far these networks work on and with states. Non-governmental organisations (NGOs) and social movements constitute 
formidable political forces in their own right, and are endowed with the potential to shape how international influence is exercised. Conflicts and alignments between state authorities and civil society networks influence which official foreign policy positions are assumed and how a country interfaces with the international (Castells, 1997; Brysk, 2000). Turkey provides a prominent example here. As the neoconservative Justice and Development Party (Adalet ve Kalkinma Partisi, abbreviated AKP in Turkish) came to power in 2002, the Turkish government established strategic alliances with a number of Islamic philanthropic NGOs and civil society associations that focus on charity work in developing countries. This alliance is based on a shared goal of promoting 'Islamic modernisation' and works through the exchange of political support to the AKP for government support of Islamic charity activities abroad (Apaydin, 2012).

Finally, the international ramifications of domestic factors are not limited to state-business and state-civil society alignments. The distribution of economic resources more broadly, and its entwining with categorical inequalities and political cleavages (Tilly, 1998), often has substantial ripple effects on international policymaking. For example, in post-apartheid South Africa, the persistence of stark ethnoracial divisions and the sharp increase in income differentials between rich and poor fostered a peculiar business climate. South African companies seek markets abroad and pressure the national government to promote new investment opportunities in sub-Saharan Africa, while the majority of the population of townships persists in a state of 'abjection' (see Ferguson, 1990) and is not even considered part of the economic equation (Carmody, 2012).

Taken together, our discussion so far emphasises the importance of domestic politics and the political economy dynamics of a country when seeking to account for international power projection. Specifically, the individual case studies point to the central roles played by natural resource access, state-business relations, civil society networks and economic inequalities in prompting state authorities in South Africa, South Korea, Turkey and Mexico to adopt a particular mode of international engagement. What kinds of natural resources are needed for sustaining economic growth, which economic sectors and civil society networks are particularly powerful and how domestic cleavages are patterned has major ramifications for how states intent to interface with the global politics of development. At the same time, the motivation to seek leadership in international organisations or facilitate trade with developing countries needs to be complemented by the capacity to pursue such a mode of international engagement.

\section{Capacities and Constraints}

What enables countries in the shadow of the BRICs to project international influence? The capacity to engage in issue leadership, opportunity seeking, and region organising and mobilising is linked to the combination of a variety of factors, both material and ideational. A constructivist perspective suggests that the ability of states to exert international influence is crucially shaped by their symbolic resources, that is, their 'identity' and reputation within the international state system (Wendt, 1999). Organisational materialism in macro-sociology puts a greater emphasis on the institutional resources and focuses on the infrastructural power of states, or the ability to 'make things work' and actually implement their international projects (Mann, 1993). Finally, the case studies assembled here suggest that international power projection is relational. It depends on the position of states relative to other countries and alliances of countries within the global 
order, and it also depends on the response international projects elicit from the 'recipient' countries on which power is exercised.

Middle power theory has long emphasised that the ability to project international influence is not just a function of demographic size, economic strength or military might (Higgott and Cooper, 1990; Pratt, 1990). Symbolic power is of equal, if not greater, importance. ${ }^{6}$ Countries may gain momentum within the global politics of development based on how other states perceive them and the extent of leadership and authority that is attributed to them within the international state community. At the most basic level, regime type is a critical source of leverage. With the recent third wave of democratisation formal democracy has become a global norm or world-cultural model (Meyer et al, 1997), and recent economic risers whose political organisation does not adhere to this standard are less able to claim the legitimate standing necessary to engage in issue leadership or regional organising. For example, it is hard to imagine that a pre-apartheid South Africa could have played the role in WTO negotiations it plays today, or that an authoritarian Turkey would be able to exercise leadership in the BSEC.

Beyond regime type, it is historically specific and often culturally charged identity discourses that constrain or facilitate the influence of economic risers in the global politics of development. South Africa's intermediary role in WTO trade negotiations feeds on the country's international recognition as a champion of human rights since the end of apartheid, and, since its highly publicised legal battle with transnational pharmaceutical companies in 1998-2001, as a champion of fair trade (Deere, 2009). This reputation persists, even though the recent South African governments of Mbeki and Zuma have turned a blind eye on human rights violations in neighbouring countries, and have generally promoted the neoliberal agenda of further trade liberalisation (Jordaan, 2012). Another example is Turkey's engagement in sub-Saharan Africa. Especially, in negotiations with officials from countries with a sizable Muslim population, Turkish state authorities frequently emphasise Turkey's 'clean past' as a non-colonising nation and highlight strong religious affinities among cultural peers as the motivation behind their engagement (Apaydin, 2012). These two cases illustrate that public diplomacy and the ability to exercise international influence are to an important extent shaped by collective imageries about a particular country and its role within the global order.

The symbolic recognition of states is analytical distinct, yet often connected to their institutional resources. State authorities actively manage their international reputation most prominently through diplomacy, the most fundamental activity of international politics (Pouliot, 2008). Diplomacy is a nodal point that underpins issue leadership, opportunity seeking, region organising and region mobilising alike. In addition, the quality of diplomacy varies. It crucially depends on the presence of a professionally trained and well-financed diplomatic service that is organised around long-term job security and merit-based promotion. States endowed with a high-quality diplomatic service are better able to communicate and negotiate a particular international agenda. A point in case here is South Korea and its focus on becoming a leader on development issues within the G20 - a role the country would be hard-pressed to assume in the absence of a highly skilled diplomatic corps with the capacity to effectively mediate among competing interests within this forum (Kalinowski and Cho, 2012).

The ability of states to carry out their international projects is not just a function of diplomacy. More generally, this ability is crucially shaped by bureaucratic professionalism and the institutional capability to implement policy choices (Evans and Rauch, 1999; Soifer and vom Hau, 2008). State authorities that cannot deliver on their compromises 
with other states are likely to face severe obstacles when seeking to maintain a position of international influence in the long run. Bilateral agreements remain paper tigers, unless they are accompanied by the implementation of new tariffs and the mobilisation of private investments, both central tasks of state organisations. For instance, Turkey's recent signing of trade protocols with Kenya and Tanzania, and its provision of ODA to Sudan and Togo, entailed the opening up of new consulates across formerly neglected zones and incentives for Turkish businesses and NGOs to invest in infrastructural development projects such as roads, water and electricity. All these measures require the commitment of substantial institutional resources from state authorities (Apaydin, 2012).

Finally, international power projection is also relational and requires close attention to the geopolitical position of states within the global state system, as well as the response international projects elicit from 'receiving' states. The relationship to the United States as the current sole superpower and the relative strength vis-à-vis other countries within a regionally circumscribed area are crucial determinants of how economic risers interface with the global politics of development. The starkest example here is Mexico: by signing NAFTA, Mexico was politically and economically separated from Latin America, where it was one of the stronger countries, and joined the United States and Canada to become the weakest part of this new regional group. This position severely limits Mexico's projection of influence in Latin America and beyond (Shadlen, 2012). Similarly, the opportunities for regional organising and mobilising are circumscribed for South Korea. Its geographical position in between China and Japan constrains the country's leverage within Southeast Asia and reinforces a global orientation in development policy (Kalinowski and Cho, 2012).

Turkey's circumscribed role in Central Asia illustrates the second relational aspect of international power projection. Depending on their political regimes and official ideologies, receiving states may oppose the international projects pursued by recent economic risers. Since the end of the Cold War, Turkey sought to extend its influence within the region through a combination of private and public ODA. Yet, especially in Kazakhstan, this strategy faced substantial resistance. The secular and clan-based authoritarian regime that currently prevails in this country perceives Islamic charities as threat to its own attempts to establish basic social welfare schemes. Consequently, Kazakh ruling elites systematically curtail the activities of Turkish Islamic philanthropy organisations, thereby confining ODA flows to a limited number of official assistance programmes (Apaydin, 2012).

In sum, this section has developed an analytical framework that identifies major determinants of international power projection among recent economic risers in the shadow of the BRICs. Comparative insights derived from case studies of South Africa, South Korea, Turkey and Mexico included in this special issue show that changing global opportunities and pressures related to economic globalisation and the rise of the BRICs, have set the stage for new forms of international engagement among these states. In turn, domestic politics and political economy dynamics, in particular natural resources access, state-business relations, civil society networks and domestic inequalities, motivate state authorities to become involved in the global politics of development, whereas symbolic resources, institutional resources, and the relative position vis-à-vis great powers and 'receiving' states shape the capacity of these economic risers to engage in issue leadership, global opportunity seeking, region organising and/or region mobilising. The broader implications of these distinct modes of international engagement are the subject of the next section. 


\section{Implications for the Global Politics of Development}

The modes of international engagement that are examined in this volume are not universal, and are not being put forward as an exhaustive list of the ways in which economic risers seek to increase their global influence. Some countries that have achieved similar, or even greater, economic improvement over recent decades have not demonstrated any of the patterns of behaviour that have been highlighted here. Furthermore, given that our analysis above highlights the importance of domestic political and economic factors in determining behaviour, no universal behavioural tendencies among rising economic powers can be expected. For this reason, an approach based on case studies is most appropriate.

Although three of the four countries - that is, South Africa, South Korea and Turkey engage in regional leadership, establish South-South partnerships and broker deals within global institutions, it is obvious that they cannot hope to influence the world in all areas that is the preserve of great powers and emerging great powers, such as the BRICs. Instead, these recent economic risers exert influence in certain other countries, in certain regions and/or in certain international organisations. The three countries thus do not pose an outright challenge to the established international order. Instead, these states remain focused on improving their position and carving out a particular niche through cooperation and mediation. In other words, these states seek to amend the international state system through the pursuit of a reformist agenda of incremental change. This mirrors the position of the BRICs, which are generally found to be 'status quo' powers (Johnston, 2003) or 'system reforming' rather than 'revisionist' (Pearson, 2006), because they have little to gain from radically altering the system that has enabled their rise. ${ }^{7}$ Issue leaders are likely to be most transformative in their approach, but even here their influence is heavily circumscribed. South Africa, for instance, has pushed strongly for altering the WTO's trade rules to make them more developmentally sensitive and increase the benefits flowing to developing countries. Yet this is within the context of strong support for the multilateral trade system and a desire to strengthen it, rather than radically alter its current approach (Jordaan, 2012).

Although this observation is true for the four countries examined in this issue, there are other recent economic risers that have taken a more radical, system-transforming approach. These include Iran and Venezuela, and it is useful to consider briefly why they have taken a different direction. As argued above, key factors in determining the behaviour of economic risers beyond the BRICs are their individual state-society relations, their political economy and their relative position within the international state system. Iran and Venezuela share two characteristics in this regard. First, they each have governments that are highly critical of the United States. For Iran, this stems from the history of Western intervention in the country, most notably the US-UK-backed 1953 overthrow of the Mossadeq government and the subsequent instalment of the unpopular and brutal regime under Shah Pahlavi. In Venezuela, the popular President Chavez also has reacted strongly against the history of US intervention in Latin America, and regularly rails against US 'imperialism'. Their confrontational stance with respect to the United States is likely to limit the degree to which they can engage in the kinds of power projection examined here, as they will face strong US opposition and limitations to alliance-building. Second, both countries owe their economic success almost exclusively to the high price of oil. As such, they have little interest in forging free trade agreements (oil is seldom subject to any form of trade restriction). For both countries, their principal form of projecting 
international power is through regional partnerships based on petro-dollar based largesse. As a result, their impact is most likely to be in the area of geopolitics (such as through Iranian attempts to undermine the position of the dollar as the universal currency for oil transactions) rather than the politics of development.

Whether system reforming or revisionist, the crucial point to note is that in the coming decades it will become critical to examine the strategies adopted by countries beyond the economic giants that have previously dominated global politics now joined by the BRICs. A second group of states will play an important role in a variety of areas that will be important in the regional and multilateral governance of development.

\section{Conclusion and Overview}

This article and the case studies it introduces is a first approach at examining sytematically the emergence of a group of countries 'beyond the BRICs'. We have argued that focusing too much attention on the BRICs risks missing the emergence of a second tier of rising economies with significant influence on the global politics of development. On the basis of case studies of South Africa, South Korea, Turkey and Mexico, we have identified four modes of international engagement that are evidenced in the subsequent papers: issue leadership, region organising, opportunity seeking and region mobilising. The particular strategy(ies) these countries use to cement their rising economic position and to exert international influence are varied, and depend on their particular circumstances and national characteristics. ${ }^{8}$

The special issue unfolds as follows. Following this introduction, Roberto Patricio Korzeniewicz's paper contextualises the case studies by examining the long-term global trends in per capita income and inequality between nations. Korzeniewicz identifies a small number of economic risers beyond India and China, while also demonstrating the persistence of a stark overall stratification between high-income countries and those trying to catch up.

The next five papers illustrate distinct strategies of international engagement through case studies of South Africa, South Korea, Turkey and Mexico. The first one focuses on regionally bounded strategies of influence. Padraig Carmody's paper examines on South Africa's political and economic role within sub-Saharan Africa, particularly within NEPAD (The New Partnership for Africa's Development) and other regional governance initiatives. It explores the political economy of South African private and public geogovernance and its impacts on the sub-continent to identify the strategies of regional engagement pursued by the South African state. Ultimately, the paper argues that the nature of South Africa's influence within the region depends on how the country deals with its own internal developmental contradictions, especially those related to domestic distributional conflicts, and the country's position vis-à-vis China.

The next set of three papers focuses on global strategies of engagement. South Korea has recently joined the group of industrialised nations, becoming a member of the OECD and the G20. However, its experience as a developing country remains within memory, and Korea has attempted to position itself as a broker between developing and developed world. However, as Thomas Kalinowski and Hyekyung Cho argue in their paper, the country's engagement with the developing world, for example through its fast rising ODA and promotion of the 'Seoul Development Consensus', has been problematic. The 
model of development promoted by Korea is 'cherry picked' from selective elements of its development history, customised to cater to Korea's current economic interests abroad.

Similarly, Fulya Apaydin's paper puts the analytical spotlight on ODA, and more generally on the role of non-state actors and recipient states, when exploring Turkey's involvement in the global politics of development. Over the last decade, the country has become a significant source of aid to Less Developed Countries (LDCs). The paper shows that Turkish ODA exhibits a curious variation. In some LDCs, as exemplified by Sudan, Turkish state agencies systematically cooperate with Islamic philanthropy organisations in the provision of development aid, whereas in other developing countries, most prominently Kazakhstan, such public-private cooperation is rare. Apaydin's explanatory argument suggests that the regime type and official ideology of recipient states are to a large extent responsible for these distinct patterns of Turkish ODA provision.

Eduard Jordaan's contribution examines how South Africa exercises influence within the global politics of development. It argues that, for South Africa, a key channel of influence is to work through multilateral institutions, both at the regional and the international level. Specifically, the paper compares South Africa's main strategies of engagement within the UN, the WTO and the India-Brazil-South Africa Dialogue Forum. The paper shows that across these different organisations, South Africa's international engagement remains torn between support for the declared values of the global economic order and loyalty to other developing countries. Jordaan highlights the role played by domestic political factors, in particular distributional conflicts and the re-racialisation of politics, in shaping South Africa's often contradictory foreign policy.

The final paper serves as a cautionary tale. Not all economic risers manage to establish greater international influence. Mexico, for much of the twentieth century an issue leader among developing countries and a regional organiser in the context of Latin America, is a point in case here. Ken Shadlen's paper is a case study of Mexico's response to the TRIPS Agreement. It analyses why the country constitutes a major exception among industrialising countries when it comes the intellectual property rights. Mexico has strengthened patents for incremental innovation and does not engage in compulsory licensing in the pharmaceutical sector, significantly diminishing the country's capacity to provide accessible healthcare. The paper argues that Mexico's puzzling behaviour is linked to the fact that the NAFTA-driven economic integration eroded the basis for possible state-business coalitions in favour of intellectual property rights reforms.

Taken together, this collection of papers argues that there is a set of countries beyond Brazil, India and China that are emerging to a position of increased international prominence and which merit greater attention than they have hitherto received. If we wish to understand the global politics of development, it is important to recognise the ways in which these countries are responding to their economic growth and seeking to secure greater influence within global affairs. We identify four such strategies - issue leadership, opportunity seeking, region organising and region mobilising - and highlight the importance of understanding the domestic politics and global embeddedness of each country in seeking to understand why a state adopts a particular strategy. On the basis of this analysis, we show that there is space for incremental changes within the global political order, and that this change is to an important extent propelled by countries emerging 'beyond the BRICs'. 


\section{Acknowledgement}

Earlier versions of this essay were presented at two workshops on 'Emerging Powers and the Global Politics of Development' at the University of Manchester in June and December 2010. We are grateful for the generous support of this research by a research network grant (RES-075-25-0018) of the Economic and Social Research Council (ESRC). We would like to especially thank the workshop participants, Knud Erik Jørgensen and Rorden Wilkinson for their detailed comments on the argument developed here. Direct correspondence to Matthias vom Hau, Institut Barcelona d'Estudis Internacionals (IBEI), Elisabets 10, Barcelona, 08001, Spain.

\section{Notes}

1. When employing the term 'BRICs' we defer to common usage following the coining of the term by Wilson and Purushothaman (2003), even though we refer primarily to Brazil, India and China. The inclusion of Russia within this category is problematic because the country does not represent a rising power, especially in light of its pre-1991 history (Macfarlane, 2006).

2. For the framework of this special issue Mexico constitutes a 'negative case', that is, an economic riser with only limited international influence. See Mahoney and Goertz (2004) on the importance of negative cases for comparative analysis.

3. South Africa has maintained its relative standing within the global income hierarchy since the 1960s (Korzeniewicz, 2012).

4. See Rueschemeyer (2009) for the distinction between theories and theory frames.

5. 'S Korea, Peru reach free trade pact to expand trade' People's Daily Online, 1 September 2010. http://english.peopledaily.com.cn/90001/90778/90858/90863/7124456.html (accessed 16 May 2011).

6. For the concept of symbolic power see Loveman (2005).

7. A possible exception is India (Narlikar, 2010).

8. Our focus is largely on state action. Less attention is paid to the private and non-governmental sectors, because we analyse the arena of international politics, which remains largely the preserve of states. Also, these countries for the most part lack companies of sufficient size to deserve particular attention (Boston Consulting Group, 2006; Fortune, 2011).

\section{References}

Acharya, A. (2009) Constructing a Security Community in Southeast Asia: ASEAN and the Problem of Regional Order, 2nd edn. New York: Routledge.

Amsden, A. (2001) The Rise of 'The Rest': Challenges to the West From Late-Industrializing Economies. Oxford: Oxford University Press.

Apaydin, F. (2012) Overseas development aid across the global south: Lessons from the Turkish experience in Sub-Saharan Africa and Central Asia. European Journal of Development Research 24(2): 261-282.

Aydin, M. (2000) Determinants of Turkish foreign policy: Changing patterns and conjunctures during the cold war. Middle Eastern Studies 36(1): 103-139.

Baran, Z. (2008) Turkey and the Wider Black Sea region. In: D. Hamilton and G. Mangott (eds.) The Wider Black Sea Region in the 21st Century: Strategic, Economic and Energy Perspectives. Washington DC: Center for Transatlantic Relations, pp. 87-102.

Barber, J. and Barratt, J. (1990) South Africa's Foreign Policy: The Search for Status and Security 1945-1988. New York: Cambridge University Press.

Barnett, M.N. and Duvall, R. (2004) Power in Global Governance. New York: Cambridge University Press.

Boston Consulting Group. (2006) The new global challengers, http://www.bcg.com/documents/ file20519.pdf, accessed 18 April 2011.

Brysk, A. (2000) From Tribal Village to Global Village: Indian Rights and International Relations in Latin America. Stanford, CA: Stanford University Press. 
Carmody, P. (2012) Another BRIC in the wall? South Africa's developmental impact and contradictory rise in Africa and beyond. European Journal of Development Research 24(2): 223-241.

Castells, M. (1997) The Power of Identity. Malden, MA: Blackwell.

Cotula, L., Verneulen, S., Leonard, R. and Keeley, J. (2009) Land Grab or Development Opportunity? Agricultural Investment and International Land Deals in Africa. London: FAO, IIED and IFAD.

Deere, C. (2009) The Implementation Game. The TRIPS Agreement and the Global Politics of Intellectual Property Reform in Developing Countries. Oxford and New York: Oxford University Press.

Dosman, E.J. (2008) Brazil and Mexico: The politics of continental drift. In: D. Drache (ed.) Big Picture Realities: Canada and Mexico at the Crossroads. Ontario, Canada: Wilfrid Laurier University Press, pp. 219-236.

Evans, P. and Rauch, J. (1999) Analysis of 'Weberian' state structures and economic growth. American Sociological Review 64(5): 748-765.

Ferguson, J. (1990) The Anti-Politics Machine: 'Development,' Depoliticization, and Bureaucratic Power in Lesotho. New York: Cambridge University Press.

Fortune. (2011) Global 500: Annual ranking of the world's largest corporations, http://money .cnn.com/magazines/fortune/global500/2010/index.html, accessed 18 April 2011.

Friedberg, A.L. (2005) The future of US-China relations: Is conflict inevitable? International Security 30(2): 7-45.

Held, D., McGrew, A., Goldblatt, D. and Perraton, J. (1999) Global Transformation: Politics, Economics and Culture. Cambridge, UK: Polity.

Higgott, R.A. and Cooper, A.F. (1990) Middle power leadership and coalition building: Australia, the Cairns Group and the Uruguay Round of trade negotiations. International Organization 44(4): 589-632.

Ismail, F. (2012) Reflections on a new democratic South Africa's role in the multilateral trading system. In: R. Wilkinson and J. Scott (eds.) Trade, Poverty, Development: Getting Beyond the WTO's Doha Deadlock. New York: Routledge.

Johnston, A.I. (2003) Is China a status quo power? International Security 27(4): 5-56.

Jordaan, E. (2012) South Africa, multilateralism and the global politics of development. European Journal of Development Research 24(2): 283-299.

Kalinowski, T. and Cho, H. (2012) Korea's search for a global role between hard economic interests and soft power. European Journal of Development Research 24(2): 242-260.

Keohane, R.O. (1969) Lilliputians' dilemmas: Small states in international politics. International Organization 23(2): 291-310.

Kohli, A. (2009) Nationalist versus dependent capitalist development: Alternate pathways of Asia and Latin America in a globalized world. Studies in Comparative International Development (SCID) 44(4): 386-410.

Korzeniewicz, R.P. (2012) Trends in world income inequality and the 'Emerging Middle'. European Journal of Development Research 24(2): 205-222.

Lange, M., Mahoney, J. and vom Hau, M. (2006) Colonialism and development: A comparative analysis of Spanish and British colonies. American Journal of Sociology 111(6): 1412-1462.

Loveman, M. (2005) The modern state and the primitive accumulation of symbolic power. American Journal of Sociology 110(6): 1651-1683.

Macfarlane, S.N. (2006) The 'R' in BRICs: Is Russia an emerging power? International Affairs 82(1): 41-57.

Mahoney, J. and Goertz, G. (2004) The possibility principle: Choosing negative cases in comparative research. American Political Science Review 98(4): 653-669.

Mann, M. (1993) The Sources of Social Power. Volume 2: The Rise of Classes and Nation States 1760-1914. New York: Cambridge University Press.

Meyer, J.W., Boli, J., Thomas, G.M. and Ramirez, F.O. (1997) World society and the nation-state. American Journal of Sociology 103(1): 144-181.

Milanovic, B. (2010) The Haves and the Have-Nots: A Brief and Idiosyncratic History of Global Inequality. New York: Basic Books.

Narlikar, A. (2010) New Powers: How to become One and how to Manage them. New York: Columbia University Press.

Nye Jr, J.S. (1990) Soft power. Foreign Policy 80(Autumn): 153-171. 
Pearson, M. (2006) China in Geneva: Lessons from China's early years in the world trade organization. In: A.I. Johnston and R.S. Ross (eds.) New Directions in the Study of China's Foreign Policy. Stanford, CA: Stanford University Press, pp. 242-275.

Phillips, N. (2003) The rise and fall of open regionalism? Comparative reflections on regional governance in the Southern Cone of Latin America. Third World Quarterly 24(2): 217-234.

Pouliot, V. (2008) The logic of practicality: A theory of practice of security communities. International Organization 62(2): 257-288.

Pratt, C. (ed.) (1990) Middle power internationalism and global poverty. In: Middle Power Internationalism: The North-South Dimension. Montreal, Canada: McGill-Queen's University Press, pp. 3-24.

Ramo, J.C. (2004) The Beijing Consensus. London: The Foreign Policy Centre.

Rueschemeyer, D. (2009) Usable Theory: Analytic Tools for Social and Political Research. Princeton, NJ: Princeton University Press.

Schneider, B.R. (2004) Business Politics and the State in Twentieth-Century Latin America. New York: Cambridge University Press.

Segal, G. (1999) Does China matter? Foreign Affairs 78(5): 24-36.

Shadlen, K. (2012) The Mexican exception: Patents and innovation policy in a non-conformist and reluctant middle income country. European Journal of Development Research 24(2): 300-318.

Shafer, D.M. (1994) Winners and Losers: How Sectors Shape the Developmental Prospects of States. Ithaca, NY: Cornell University Press.

Soares de Lima, M. and Hirst, M. (2006) Brazil as an intermediate state and regional power: Action, choice and responsibilities. International Affairs 82(1): 21-40.

Soifer, H. and vom Hau, M. 2008 Unpacking the strength of the state: The utility of state infrastructural power. Studies in Comparative International Development 43(3-4): 219-230.

Tilly, C. (1998) Durable Inequality. Berkeley, CA: University of California Press.

Wade, R. (2010) After the crisis: Industrial policy and the developmental state in low-income countries. Global Policy 1(2): 150-161.

Waldner, D. (1999) State Building and Late Development. Ithaca, NY: Cornell University Press.

Wendt, A. (1999) Social Theory of International Politics. New York: Cambridge University Press.

Wilson, D. and Purushothaman, R. (2003) Dreaming with the BRICs: The Path to 2050. New York: Goldman Sachs. Global Economics Paper No. 99.

Zweig, D. and Jianhai, B. (2005) China's global hunt for energy. Foreign Affairs 84(5): 25-38. 